\title{
Microbiological and molecular monitoring for bovine tuberculosis in the Polish population of European bison (Bison bonasus)
}

\author{
Anna Didkowska ${ }^{1, A-F}{ }^{\oplus}$, Blanka Orłowska ${ }^{1, A-C, F \oplus}{ }^{\oplus}$, Monika Krajewska-Wędzina ${ }^{2, A, C, F}{ }^{\oplus}$, \\ Ewa Augustynowicz-Kopeć ${ }^{3, A-C, F \oplus}$, Sylwia Brzezińska ${ }^{3, B-C, E-F \oplus}{ }^{\oplus}$ Marta Żygowska ${ }^{1, A-B, D, F} \oplus$, \\ Jan Wiśniewski ${ }^{1, B-C, F} \oplus$, Stanisław Kaczor ${ }^{4, B, F}{ }^{\oplus}$, Mirosław Welz ${ }^{5, A, C, F \oplus}$, Wanda Olech ${ }^{6, A, E-F} \oplus$, \\ Krzysztof Anusz ${ }^{1, A-F} \odot$ \\ ${ }^{1}$ Department of Food Hygiene and Public Health Protection, Institute of Veterinary Medicine, University of Life Sciences \\ (SGGW), Warsaw, Poland \\ ${ }^{2}$ Department of Microbiology, National Veterinary Research Institute, Puławy, Poland \\ ${ }^{3}$ Department of Microbiology, National Tuberculosis Reference Laboratory, National Tuberculosis and Lung Diseases \\ Research Institute, Warsaw, Poland \\ ${ }^{4}$ County Veterinary Inspectorate, Sanok, Poland \\ ${ }^{5}$ General Veterinary Inspectorate, Warsaw, Poland \\ ${ }^{6}$ Department of Animal Genetics and Conservation, Institute of Animal Sciences, University of Life Sciences (SGGW), \\ Warsaw, Poland \\ A - Research concept and design, B - Collection and/or assembly of data, C - Data analysis and interpretation, \\ $D$ - Writing the article, E - Critical revision of the article, F- Final approval of article
}

\begin{abstract}
Didkowska A, Orłowska B, Krajewska-Wędzina M, Augustynowicz-Kopeć E, Brzezińska S, Żygowska M, Wiśniewski J, Kaczor S, Welz M, Olech W, Anusz K. Microbiological and molecular monitoring for bovine tuberculosis in the Polish population of European bison (Bison bonasus). Ann Agric Environ Med. 2021; 28(4): 575-578. doi: 10.26444/aaem/130822
\end{abstract}

\section{Abstract}

Introduction and objective. In recent years, bovine tuberculosis (BTB) has become one of the major health hazards facing the European bison (EB, Bison bonasus), a vulnerable species that requires active protection, including regular and effective health monitoring. Monitoring of zoonotic disease in wildlife is also an important part of public health protection. The aim of the study was to determine whether BTB still influences the EB population in Poland.

Materials and method. During 2017-2019, mandibular, retropharyngeal and mediastinal lymph nodes were collected from 90 EB during post-mortem examination, and then cultivated on Lowenstein-Jensen and Stonebrink media. Isolated strains were subjected to molecular analysis to determine the species, spoligotype and MIRU-VNTR pattern.

Results. Lesions were found in lymph nodes originating from eight EB (8.89\%). Positive microbiological cultures for mycobacteria were obtained in samples from six (6.67\%) EB. The isolated strains were identified as Mycobacterium caprae (material from four EB) and atypical mycobacteria (material from two EB). For M. caprae strains spoligotype M. bovis 4_CA 1600 was identified and the MIRU-VNTR pattern was identified as 345751355413232.

Conclusions. It is recommended that this potentially dangerous disease should be monitored in EB via a comprehensive strategy based on a combination of microbiological and molecular methods. Such monitoring will protect the health of both animals and humans.

\section{Key words}

monitoring, bovine tuberculosis, Mycobacterium caprae, European bison, Mycobacterium avium complex

\section{INTRODUCTION}

Almost a quarter of the global European bison (EB, Bison bonasus) population lives in Poland. The European bison Pedigree Book indicates that in 2018, the EB population in Poland comprised 1,820 individuals: 207 - closed farms, 1,613 - free-ranging herds (https://bpn.com.pl/index. php?option=com_content\&task=view\&id=1132\&Itemid=3 $06]$ ). EB is a priority species for the European Union in terms of conservation measures (species code: 2674), and despite EB being included in the VU (vulnerable to extinction)

Address for correspondence: Anna Didkowska, Department of Food Hygiene and Public Health Protection, Institute of Veterinary Medicine, University of Life Sciences (SGGW), Nowoursynowska 166, 02-787 Warsaw, Poland

Email: anna_didkowska@sggw.edu.pl

Received: 15.19.2020; accepted: 24.11.2020; first published: 10.12.2020 category in the International Union for Conservation (IUCN) Red Book of Endangered Species, its population is steadily growing (http://www.iucnredlist.org) [1]. The main goal of EB restitution now is to increase the number of free-ranging and enclosed-breeding herds $[2,3]$. In Poland, the national EB protection project places a high priority on monitoring the health of the population [4]. Such monitoring is primarily based on post-mortem examination, during which clinical material is collected for further diagnosis [5].

Suspsceptibilty to infectious diseases seems to be one of the most crucial problems but there are also existing environmental threats [6]. In the $20^{\text {th }}$ Century, a number of diseases affected the EB population in Poland, with the most significant ones being foot-and-mouth disease, posthitis and bovine tuberculosis (BTB) [7]. BTB, caused by Mycobacterium bovis and Mycobacterium caprae, is a chronic disease that has 
been found in many species of both livestock and wildlife [8, 9], including the genus Bison [10]. Not only is it important that endangered animals be monitored for BTB, but as the disease is known to have zoonotic potential, its presence in other species also needs to be tracked $[11,12]$. Even though, currently, Poland has the officially tuberculosis free $\left(\mathrm{OTF}^{1}\right)$ status, in recent years cases of $M$. bovis and $M$. caprae infection has been confirmed in wildlife $[13,14]$. Sharing pastures by free-living animals with livestock can lead to the pathogens transmission and pose a real threat to public health. Wherefore, the monitoring of BTB in EB is important for two reasons - species protection and its zoonotic nature.

Currently, despite the appearance of many new methods, the current gold standard in tuberculosis diagnosis is based on a combination of culture and molecular methods. These methods are also the most appropriate for use in postmortem monitoring. In such cases, the predilection tissue for mycobacteria isolation is that of the lymph nodes $[15,16]$.

\section{OBJECTIVES}

As the severity of the threat presented to European bison in Poland by BTB remains unclear, the aim of the present study was to determine the occurrence of mycobacteria within the population by examination of lymph nodes collected post-mortem from EB for BTB testing. The study also uses a combination of microbiological and molecular methods to classify any identified mycobacteria.

\section{MATERIALS AND METHOD}

Material collection. During 2017-2019, lymph nodes were collected from 90 European bison (EB) from various regions of Poland. The age of the EB ranged from three months to 25 years (mean age: 7.5 years). The ages of nine EB were unknown. Of the studied EB, $44.44 \%$ were from free-ranging herds (Knyszyńska Forest, Bieszczady Mountains, Borecka Forest, Białowieska Forest) and 55.56\% from breeding centres. Post-mortem examination was performed on all $\mathrm{EB}$, during which lymph nodes (mandibular, retropharyngeal and mediastinal) were collected for further examination. The nodes were delivered to the laboratory under refrigerated conditions and kept at $-20^{\circ} \mathrm{C}$ until cultures were performed.

Mycobacteria isolation. The collected lymph nodes were examined for the presence of anatomopathological lesions, with particular emphasis on tuberculous lesions. Following this, the material was subjected to standard methods for mycobacterial isolation according to Orlowska et al. (2017) [13]. Briefly, the material was homogenized in $5 \%$ oxalic acid and flushed twice in saline solution. The supernatant was then plated on Lowenstein and Stonebrink media, and incubated at $37^{\circ} \mathrm{C}$ for 12 weeks, with the growth on the media being checked every seven days.

Genetic analysis. DNA was isolated using the Genolyse isolation kit (Hain Lifescience, Germany). Based on the obtained DNA, the strains were classified as MTBC (Mycobacterium tuberculosis complex) or as 27 NTM

1. OTF - officialy tuberculosis free.
(Non-tuberculosis mycobacteria) species using the GenoType Mycobacterium CM test (Hain Lifescience). Within the MTBC group, the species were further differentiated using GenoType MTBC assay (Hain Lifescience) which is based on the polymorphism of the gyrB gene. GenoType tests are based on DNA-STRIP method which can identify PCR products by allowing them to hybridize with specific oligonucleotide probes on a nitrocellulose strip. Both tests were carried out in accordance with the manufacturer's instructions. The isolated DNA was also subjected to spoligotyping using a commercial genotyping kit (Genutaur molecular products, Kampenhout, Belgium) (https://gentaur-spain.com/wpcontent/uploads/2015/03/Spoligotyping-Manual.pdf). This method allows the polymorphism of the chromosomal DR (direct repeat) region occurring only in the genome of MTBC to be detected. The obtained patterns were compared to those of strains registered in the SpolDB4 database.

In addition, the DNA obtained for each strain was subjected to 15 amplification reactions using 15 pairs of primer sequences based on the MIRU-VNTR method. This method is based on the analysis of selected polymorphic microsatellite sequences within the mycobacterial genome. The PCR products were visualized by gel electrophoresis (2.5\% agarose gel, large gel-65V, 5 hours). The following loci were analyzed: MIRU-4, MIRU-10, MIRU-16, MIRU26, MIRU-31, MIRU-40, VNTR 424, VNTR 577, VNTR 2165, VNTR 2401, VNTR 3690, VNTR 4165, VNTR 2163b, VNTR 1955, VNTR 4052. The results are presented as a 15 -digit code. The digits indicate the number of repetitions of subsequent MIRU-VNTR repeat sequences.

\section{RESULTS}

Assessment of lesions in lymph nodes. Lesions were observed in lymph nodes originating from eight EB (8.89\%), among which four EB demonstrated caseous lesions and four presented purulent lesions.

Mycobacteria isolation. Material obtained from five EBs demonstrated growth on both types of media, manifested as rough, yellow colonies on the surface of the medium. Material from one $\mathrm{EB}$ was found to give rise to two types of colony.

Genetic analysis. Of the seven tested strains, four were classified as M. caprae, two as Mycobacterium xenopii and one as Mycobacterium avium. Further analysis of $M$. caprae found the spoligotype for these strains to be identified $M$. caprae - spoligotype M. bovis _4_ CA 1600 (octagonal pattern: 200003770003600) (SpolDB4 database). For the studied $M$. caprae strains, the MIRU-VNTR pattern was identified as 345751355413232 .

\section{DISCUSSION}

BTB cases in EB should be should be carefully analyzed and monitored. In this study, $4.44 \%$ of tested samples were found to be BTB positive. These samples were obtained from EB kept in an enclosed breeding centre where BTB had been diagnosed previously. Although cases of BTB have been noted almost every year in this herd since 2013 [17], no new BTB outbreaks occurred in EB elsewhere in Poland in the 
period 2017-2019. However, as BTB cases have been recorded in EB in Poland in previous years, it is recommended that lymph nodes from each dead EB be collected post mortem and subjected to mycobacterial examination.

European bison appear to be particularly sensitive to BTB infection, as indicated by the large number of cases observed in the past [18]. In the period 1996-2013, 45 cases of BTB were confirmed in EB (Bison bonasus caucasicus) in the Bieszczady Mountains in south-east Poland [18]. The first case concerned a three-year-old cow in which generalized tuberculosis was found during post-mortem examination [19]. Following this, in the period 2005-2008, BTB was confirmed in two EB from the Bieszczady area [20]. In 2009, an entire free-ranging herd in the Bieszczady Mountains was culled following the discovery of BTB: tuberculosis lesions were found during post-mortem examination in all herd members, and BTB was confirmed microbiologically in 23 out of 24 individuals [21].

It should be noted that since 2012, BTB cases have also been reported in wild boars in the Bieszczady Mountains. Interestingly, the strain identified in the boars demonstrated an identical spoligotype to a herd in which BTB had previously been diagnosed in 13 out of 18 individuals [14]; although the decision was made to cull the entire herd, several EB separated from the herd and could not be found [22]. The long history of BTB in the Bieszczady Mountains justifies greater monitoring for BTB, particularly in this region. In addition, in 2016, two cases of BTB were also confirmed in free-ranging EB in a herd in the Borecka Forest [23] in the Warmia-Mazuria region of north-east Poland, but no cases where confirmed in this region later [24].

Attempts have been made to isolate mycobacteria antemortem from animals in captivity, such as in zoos and breeding centres, using materials such as bronchopulmonary lavage from lions [25] or EB [26]. However, due to the difficulties associated with collecting material, indirect tests are typically used for ante-mortem diagnostics in free-ranging animals, such as the tuberculin test $[27,28]$, gamma-interferon test $[29,30,31,32]$ or serological tests $[33,34,35]$. These tests, however, are less sensitive than postmortem microbiological monitoring, and they often lack standardization for different species, including EB. For this reason, ante-mortem monitoring for BTB is not sufficient for monitoring the epizootic situation in the EB population, and material obtained post-mortem remains extremely valuable.

One of the goals of sustainable development set by the World Health Organization is to combat the global tuberculosis epidemic. It should be emphasized that data on the number of tuberculosis cases in humans are considered to be underestimated and the real scale of the problem remains unknown [36]. BTB is a dangerous zoonosis, and monitoring is needed to protect public health. Although in recent years the number of BTB infections has decreased significantly in developed countries, mainly due to wide-scale milk pasteurization and eradication programmes, cases are still observed, even in Poland [37]. Infected EB in zoos or bison breeding centres can pose a potential health risk to tourists, keepers or veterinarians.

$\mathrm{BTB}$ testing is also important in the EB population because wildlife often share pastures with livestock, and this has been found to contribute to the spread of mycobacteria [38, $39,40]$. Such sharing clearly presents a risk for EB which may come into contact with potentially infected cattle; conversely, infected EB can also pose a zoonotic risk for humans by coming into contact with livestock. For Poland to maintain the OTF status, the prevalence of BTB in freeranging animals, especially the EB and wild boars of the Bieszczady Mountains, needs to be effectively monitored. The possible loss of the OTF status would be associated with economic losses and trade restrictions, therefore it is of a great importance to monitor BTB, especially in highly sensitive species.

M. caprae have been isolated previously in European wildlife such as red deer (Cervus elaphus) [41, 42, 43, 44], red fox (Vulpes vulpes) [45] and wild boar [46]. It has also been described in wild boar (Sus scrofa), roe deer (Capreolus capreolus) and wolves (Canis lupus) in Poland [47]. The MIRUVNTR pattern obtained in the present study has not been described previously. It may be of great importance in the case of outbreaks of tuberculosis in European bison, or in other wildlife or livestock animals, especially those from the same region. Such information can help establish transmission routes and allow epidemiological investigations [48].

It is notable that atypical mycobacteria were isolated from the EB in the present study. Even though M. avium infection in animals can be asymptomatic, their occurrence should be monitored in protected species as infection is often associated with loss of condition, and the occurrence of diarrhea and weight loss [49]. In addition, the isolated mycobacteria (M. avium and M. xenopi) tend to be etiological factors of serious diseases in humans, particularly those with immune deficiency $[50,51,52]$.

\section{CONCLUSIONS}

Microbiological monitoring in 2017-2019 indicated that BTB does not currently pose a significant threat to the EB population. However, among the samples taken from bison in a breeding centrer where BTB had previously been detected, $4.4 \%$ were found to be positive for bovine mycobacteria, and $2.2 \%$ for atypical mycobacteria. No new BTB outbreaks were detected in the period 2017-2018. Despite these negative results, it is recommended that further microbiological monitoring for BTB be performed in this species.

\section{Acknowledgments}

The work was supported by the project "Complex project of European bison conservation by State Forests", which is financed by the Forest Found (Poland), contract no OR.271.3.10.2017.

\section{REFERENCES}

1. Olech W, 2018 (IUCN SSC Bison Specialist Group). Bison bonasus. The IUCN Red List of Threatened Species, e.T2814A9484719; 2018.

2. Klich D, Olech W, Cielniak K. A complex project for the conservation of European bison in Poland by State Forests, European Bison Conservation Newsletter 2017;10:11-20.

3. Klich D, Olech W, Łopucki R, et al. Community attitudes to the European bison Bison bonasus in areas where its reintroduction is planned and in areas with existing populations in northeastern Poland. Eur J Wild Res. 2018; 64: 61.

4. Olech W, Klich D, Perzanowski K. Development of a new action plan for the European bison. Oryx 2019; 53: 214-214.

5. Bielecki W, Amarowicz J, Hławiczka M, et al. Monitoring zdrowia populacji żubrów jako element ochrony gatunku. European Bison Conservation Newsletter 2014: 17; 43-50. 
6. Klich D, Łopucki R, Stachniuk A, et al. Pesticides and conservation of large ungulates: health risk to European bison from plant protection products as a result of crop depredation. PLoS One. 2020; 15: e0228243.

7. Krzysiak MK, Larska M, Jabłoński A, et al. Zakaźne i inwazyjne zagrożenia zdrowia i życia żubrów (Bison bonasus) w XX wieku. Życie Weterynaryjne 2017; 92: 654-657.

8. Rodríguez S, Bezos J, Romero B, et al. Spanish network on surveillance and monitoring of animal tuberculosis. Mycobacterium caprae infection in livestock and wildlife, Spain. Emerg Infect Dis. 2011; 17: 532-535.

9. Palmer MV. Mycobacterium bovis: Characteristics of Wildlife Reservoir Hosts. Transbound Emerg Dis. 2013; 60(Suppl. 1): 1-13.

10. Zimpel CK, Brum JS, de Souza Filho AF, et al. Mycobacterium bovis in a European bison (Bison bonasus) raises concerns about tuberculosis in Brazilian captive wildlife populations: a case report. BMC Res Notes. 2017; 10: 91.

11. Müller B, Dürr S, Alonso S, et al. Zoonotic Mycobacterium bovisinduced tuberculosis in humans. Emerg Infect Dis. 2013; 19: 899-908.

12. Torres-Gonzalez P, Cervera-Hernandez ME, Martinez-Gamboa A, et al. Human tuberculosis caused by Mycobacterium bovis: a retrospective comparison with Mycobacterium tuberculosis in a Mexican tertiary care centre, 2000-2015. BMC Infect Dis. 2016; 16: 657.

13. Orłowska B, Augustynowicz-KopećE, Krajewska M, et al., Mycobacterium caprae transmission to free-living grey wolves (Canis lupus) in the Bieszczady mountains in southern Poland. Eur J Wildl. Res. 2017; 63: 1-5.

14. Krajewska M, Lipiec M, Zabost A, et al. Bovine tuberculosis in a wild boar (Sus scrofa) in Poland. J Wildl Dis. 2014; 50: 1001-1002.

15. Prakasha SR, Suresh G, D'Sa IP, et al. Mapping the pattern and trends of extrapulmonary tuberculosis. J Glob Infect Dis. 2013; 5: 54-59.

16. Ganchua SKC, Cadena AM, Maiello P, et al. Lymph nodes are sites of prolonged bacterial persistence during Mycobacterium tuberculosis infection in macaques. PLoS Pathog. 2018; 14: e1007337. doi: 10.1371/ journal.ppat.1007337

17. Krajewska M, Orłowska B, Anusz K, et al. Gruźlica bydlęca w hodowli żubrów w Smardzewicach. Życie Weterynaryjne 2016; 91: 50-53.

18. Radulski Ł, Lipiec M, Krajewska-Wędzina M, et al. Gruźlica bydlęca u zwierząt dzikich oraz wolno żyjących - badania laboratoryjne 2008 2018. Życie Weterynaryjne 2019; 94: 51-53.

19. Żurawski C, Lipiec M. Przypadek uogólnionej gruźlicy u żubra. Med Wet. 1997; 53: 9-92.

20. Welz M. 2010. The epizootic situation among livestock and the wildlife in the area of Bieszczady Mountains considering the Mycobacterium bovis infections. PhD Dissertation. University of Life Sciences, Warsaw.

21. Brewczyński P, Welz M. Threat of tuberculosis of European bison in the Bieszczady. European Bison Conservation Newsletter 2011; 4: 63-70.

22. Welz M, Anusz K, Salwa A, et al. Bovine tuberculosis in European bison in the Bieszczady region. Med Wet. 2005; 61: 441-444.

23. Krajewska M, Kozińska M, Orłowska B, et al. Mycobacterium bovis u żubra w Puszczy Boreckiej, „Żubry w Krainie Dinozaurów”, 8-9 September 2016. Conference Materials.

24. Didkowska A, Krajewska-Wędzina M, Orłowska B, et al. Further epidemiological investigation of tuberculosis in European bison (Bison bonasus), European Bison Conservation Newsletter 2018; 11: 43-48.

25. Miller M, Buss P, Hofmeyr J, et al. Antemortem diagnosis of Mycobacterium bovis infection in free-ranging African lions (Panthera leo) and implications for transmission. J Wildl Dis. 2015; 51: 493-497.

26. Anusz K, Orłowska B, Krajewska-Wędzina M, et al. Ante-mortem and post-mortem tuberculosis diagnostics in three European Bison (Bison bonasus caucasicus) from the enclosure in Bukowiec in the Bieszczady National Park in Poland. Med Wet. 2017; 73: 642-646.

27. Viljoen IM, Sylvester TT, Parsons SDC, et al. Performance of the tuberculin skin test in Mycobacterium bovis-exposed and-unexposed African lions (Panthera leo). J Wildl Dis. 2019; 55(3): 537-543. doi: 10.7589/2018-06-163

28. Roos EO, Olea-Popelka F, Buss P, et al. Measuring antigen-specific responses in Mycobacterium bovis-infected warthogs (Phacochoerus africanus) using the intradermal tuberculin test. BMC Vet Res. 2018; 14(1): 360. doi: 10.1186/s12917-018-1685-8

29. Buzdugan SN, Chambers MA, Delahay RJ, et al. Quantitative interferongamma responses predict future disease progression in badgers naturally infected with Mycobacterium bovis. Epidemiol and Infect. 2017; 145: 3204-3213.

30. Bernitz N, Clarke C, Roos EO, et al. Detection of Mycobacterium bovis infection in African buffaloes (Syncerus caffer) using QuantiFERON.TB Gold (QFT) tubes and the Qiagen cattletype IFN-gamma ELISA. Vet Immunol Immunopathol. 2018; 196: 48-52.

31. Chileshe J, Roos EO, Goosen WJ, et al. An interferon-gamma release assay for the diagnosis of the Mycobacterium bovis infection in white rhinoceros (Ceratotherium simum). Vet Immunol Immunop. 2019; 217: 109931. doi: 10.1016/j.vetimm.2019.109931

32. Higgitt RL, Schalkwyk OLV, de Klerk-Lorist LM, et al. An interferon gamma release assay for the detection of immune sensitization to Mycobacterium bovis in african wild dogs (Lycaon pictus). J Wildl Dis. 2019; 55: 529-536.

33. Lyashchenko KP, Greenwald R, Esfandiari J, et al. Animal-side serologic assay for rapid detection of Mycobacterium bovis infection in multiple species of free-ranging wildlife. Vet Microb. 2008; 132: 283-292.

34. 34 Miller MA, Buss P, Sylvester TT, et al. Mycobacterium bovis in free-ranging lions (Panthera leo) - evaluation of serological and tuberculin skin tests for detection of infection and disease. J Zoo Wildlife Med. 2019; 50: 7-15.

35. Krajewska-Wędzina M, Didkowska A, Sridhara AA, et al. Transboundary tuberculosis: Importation of alpacas infected with Mycobacterium bovis from the United Kingdom to Poland and potential for serodiagnostic assays in detecting tuberculin skin test false-negative animals. Transbound Emerg Dis. 2020, doi: 10.1111/tbed.13471

36. Olea-Popelka F, Muwonge A, Perera A, et al. Zoonotic tuberculosis in human beings caused by Mycobacterium bovis-a call for action. Lancet 2017; 17: 21-25.

37. Kozińska M, Krajewska-Wẹdzina M, Augustynowicz-Kopeć E. Mycobacterium caprae - the first case of the human infection in Poland. Ann Agric Environ Med. 2019. doi: 10.26444/aaem/108442

38. Malama S, Muma JB, Godfroid J. A review of tuberculosis at the wildlife-livestock-human interface in Zambia. Infect Dis Poverty 2013; 2: 13. doi: 10.1186/2049-9957-2-13

39. Mohamed A. Bovine tuberculosis at the human-livestock-wildlife interface and its control through one health approach in the Ethiopian Somali Pastoralists: A review. One Health 2019; 9: 100113. doi: 10.1016/j. onehlt.2019.100113

40. Rossi G, Aubry P, Dubé C, et al. The spread of bovine tuberculosis in Canadian shared pastures: Data, model, and simulations. Transbound Emerg Dis. 2019; 66: 562-577.

41. Prodinger WM, Eigentler A, Allerberger F, et al. Infection of red deer, cattle, and humans with Mycobacterium bovis subsp. caprae in western Austria. J Clin Microbiol. 2002; 40(6): 2270-2. doi: 10.1128/ jcm.40.6.2270-2272.2002

42. Schoepf K, Prodinger WM, Glawischnig W, et al. A Two-Years' Survey on the Prevalence of Tuberculosis Caused by Mycobacterium caprae in Red Deer (Cervus elaphus) in the Tyrol, Austria. ISRN Vet Sci. 2012 doi: 10.5402/2012/245138

43. Nigsch A, Glawischnig W, Bagó Z, et al. Mycobacterium caprae infection of red deer in Western Austria-Optimized Use of Pathology Data to Infer Infection Dynamics. Front Vet Sci. 2018; 5: 350. doi: 10.3389/ fvets.2018.00350

44. Dorn-In S, Körner T, Büttner M, et al. Shedding of Mycobacterium caprae by wild red deer (Cervus elaphus) in the Bavarian alpine regions, Germany. Transboundary Emerg Dis. 2020; 67: 308-17. doi: 10.1111/ tbed.13353

45. Steinparzer R, Stanclova G, Bagó Z, et al. Generalized Tuberculosis due to Mycobacterium caprae in a Red Fox (Vulpes vulpes) in Austria. J Wildl Dis. 2020 doi: 10.7589/2019-10-249

46. Vieira-Pinto M, Alberto J, Aranha J. et al. Combined evaluation of bovine tuberculosis in wild boar (Sus scrofa) and red deer (Cervus elaphus) from Central-East Portugal. Eur J Wildl Res.2011; 57: 1189. https://doi.org/10.1007/s10344-011-0532-z

47. Orłowska B, Krajewska-Wędzina M, Augustynowicz-Kopeć E, et al. Epidemiological characterization of Mycobacterium caprae strains isolated from wildlife in the Bieszczady Mountains, on the border of Southeast Poland. BMC Vet Res. 2020; 29: 362. doi: 10.1186/s12917020-02581-3

48. Erler W, Martin G, Sachse K, et al. Molecular fingerprinting of Mycobacterium bovis subsp. caprae isolates from central Europe. J Clin Microbiol. 2004; 42(5): 2234-8. doi: 10.1128/jcm.42.5.2234-2238.2004

49. Fecteau ME. Paratuberculosis in cattle. Vet Clin North Am Food Anim Pract. 2018; 34(1): 209-222. doi: 10.1016/j.cvfa.2017.10.011

50. Sharma K, Sharma A, Appannanavar S, et al. Mycobacterium avium meningitis in HIVpatients in North India. AIDS Res Hum Retroviruses. 2013; 29: 849-850. doi: 10.1089/AID.2012.0332

51. Kuntz M, Seidl M, Henneke P. Osteomyelitis because of Mycobacterium xenopi in an immunocompetent child. Ped Infect Dis J. 2016; 35: 110-113. doi: 10.1097/INF.0000000000000933

52. Stjepanovic MI, Pesut DP, Lesic AR, et al. Pulmonary and vertebral Mycobacterium avium disease in a HIV-negative 71-year-old Man - A Case Report. Infez Med. 2016; 24: 345-348. 